NBER WORKING PAPER SERIES

\title{
THE GLOBALIZATION OF THE SOFTWARE INDUSTRY: PERSPECTIVES AND OPPORTUNITIES FOR DEVELOPED AND DEVELOPING COUNTRIES
}

\author{
Ashish Arora \\ Alfonso Gambardella \\ Working Paper 10538 \\ http://www.nber.org/papers/w10538 \\ NATIONAL BUREAU OF ECONOMIC RESEARCH \\ 1050 Massachusetts Avenue \\ Cambridge, MA 02138 \\ June 2004
}

We gratefully acknowledge support from the Software Industry Center at Carnegie Mellon, and its sponsors, especially the Alfred P. Sloan Foundation. We have also benefited from the colleagues participating in the Software Industry Center's Globalization of the Software Industry Project, and from comments we received on an earlier version of this paper from the editors of this volume. Needless to say, the views expressed in this paper are ours, as are any errors and deficiencies. The views expressed herein are those of the author(s) and not necessarily those of the National Bureau of Economic Research.

(C)2004 by Ashish Arora and Alfonso Gambardella. All rights reserved. Short sections of text, not to exceed two paragraphs, may be quoted without explicit permission provided that full credit, including $(\mathrm{C}$ notice, is given to the source. 
The Globalization of the Software Industry: Perspectives and Opportunities for Developed and Developing Countries

Ashish Arora and Alfonso Gambardella

NBER Working Paper No. 10538

May 2004

JEL No. O3, O5

\section{$\underline{\text { ABSTRACT }}$}

The spectacular growth of the software industry in some non-G7 economies has aroused both interest and concern. This paper addresses two sets of inter-related issues. First, we explore the determinants of these successful stories. We then touch upon the broader question of what lessons, if any, can be drawn from for economic development more generally. Finally, examining the long term implications of offshoring of software, we conclude that it is unlikely to pose a long term threat to American technological leadership. Instead, the U.S. economy will broadly benefit from the growth of new software producing regions. The U.S. technological leadership rests in part upon the continued position of the U.S. as the primary destination for highly trained and skilled scientists and engineers from the world over. Though this is likely to persist for some time the increasing attractiveness of foreign emerging economy destinations is a long-term concern for continued U.S. technological leadership.

Asish Arora

H. John Heinz III School of

Public Policy and Management

Carnegie Mellon University

Pittsburgh, PA 15213

ashish@andrew.cmu.edu

Alfonso Gambardella

Sant' Anna School of Advanced Studies

Pisa, Italy

gambardella@sssup.it 


\section{Introduction}

One rather unexpected phenomenon of the 1990s has been the spectacular growth of the software industry in some non-G7 economies. The first element of surprise is that these are not countries where one would expect to see the growth of what is commonly thought of as a high-tech. The second element is that what the 1990s have shown is not just growth of the industry, but a remarkable growth. In India, for example, software production was virtually non-existent in the early 1980s. Today software employs more than 450,000 employees, sustaining annual growth rates of $30-40 \%$ in revenues and employment over more than 10 years. Although less remarkable than India, countries like Ireland and Israel have also had double digit growth.

This paper addresses two sets of inter-related issues. First, we explore the determinants of these successful stories. We then touch upon the broader question of what lessons, if any, can be drawn from for economic development more generally. Second, the Indian, Irish and Israeli software industries export a substantial fraction of their output (and services) to advanced economies - particularly the U.S. There is a major debate in the U.S. regarding the desirability of outsourcing, along the familiar "free trade versus jobs" lines. Rather than join this debate, we prefer to focus on a related one, which arguably is of greater long term significance. Specifically we ask whether the growth of the software industry in emerging economies is beneficial for the U.S., and what it means for the technological leadership of the U.S. in the longer term.

In the next Section we discuss the growth of the software industry in five newcomer regions - India, Ireland, Israel, Brazil and China. This is based on the results of a two-year international project that led to a forthcoming volume (Arora and Gambardella, 2005). The five comparisons provide an interesting basis for our discussion because while the growth of India, Ireland and Israel has been fuelled by exports, China and Brazil have grown largely thanks to 
their domestic market. From the evidence collected for these countries, in Section 3 we then discuss some of the reasons why they have been successful in software. In Section 4 we discuss some of the implications of this growing international division of labor for the U.S. economy. Section 5 takes the Indian point of view. There is one effect in particular that has to be assessed more carefully, and this is the large outflow of human capital from India. We discuss the pros and cons of these flows for both India and the U.S. Section 6 discusses whether the patterns of growth of software in our five countries can provide lessons for other emerging economies, in software or in the IT industries more generally. Section 7 summarizes some of the policy implications of our analysis, while Section 8 concludes by providing some broad considerations on the topic.

\section{The Software Industry in Brazil, China, India, Ireland, and Israel}

During the 1990s India, Ireland and Israel have emerged as significant software exporters. In the same period, Brazil and China have also developed an extensive software sector relying largely on the domestic market, and are now attempting to move to exports. ${ }^{1}$ Table 1 shows that in 2002 , the Indian and Chinese industries were of comparable size (respectively $\$ 12.5$ and $\$ 13.3$ billions), while the 2001 sales of Brazil and Israel were $\$ 7.7$ and $\$ 4.1$ billions. The Irish industry reached $\$ 13.9$ billion in total sales in 2002, of which $\$ 12.3$ billion is attributed to the multinational companies and $\$ 1.6$ billion to the indigenous sector. ${ }^{2}$

\footnotetext{
${ }^{1}$ Moreover while the 3Is stand somewhat separately because of a set of peculiar features (e.g. the "Diaspora", English-speaking human capital, large export shares), the patterns observed for China and Brazil bear greater similarities with other non G7 countries. For example, in South Korea too the software industry has relied mainly on the domestic market, and on spillovers from leading industries like hardware and electronics.

${ }^{2}$ The Irish MNC sales are most likely inflated by accounting devices guided by the substantial tax concessions offered by the country. Indeed, the MNCs in Ireland have employment levels comparable to that of the indigenous firms $(15,300$ and 12,600 respectively in 2002), while their sales are over 8 times as much. Since they mostly localize their products in Ireland not design them, this gap must arise mainly from accounting reasons, not superior value added.
} 


\section{TABLE 1 ABOUT HERE}

The employment differences among our five countries are more marked than those in sales. In March 2003 the Indian software industry employed about 250,000 people. $^{3}$ The 2000 figures for China and Brazil are respectively about 160,000 and 190,000. As noted, the 2002 employment in the Irish software industry was about 28,000 (15,300 and 12,600 respectively for MNCs and indigenous firms), while the 2001 employment of the Israeli industry was about 15,000 . To put these figures in perspective, employment in the U.S. software industry was slightly above 1 million, with sales of around $\$ 200$ billion, while the comparable figures for Japan were 534,000 and $\$ 85$ billion. ${ }^{4}$ Germany, the third largest software producer had employment of around 300,000 and sales of around $\$ 40$ billion. ${ }^{5}$ The sales and employment figures produces notable differences in the sales per employee, with Israel having the highest sales per employee, followed by Ireland, whose figures are only slightly lower than the figure for Germany The revenue per employee of the Indian industry in 2002 was about $\$ 50,000$, and comparable to figures for China and Brazil.

The picture that emerges from these figures is consistent with the stylized facts. The Israeli software industry is largely product- and-R\&D oriented. The software industry in Brazil, China and India is of lower value added, and in Indian in particular, is heavily service oriented. Ireland is in between, with a handful of product oriented firms, and a number of small consultancies and niche firms.

\footnotetext{
${ }^{3}$ This excludes what NASSCOM calls IT enabled services, such as call centers and help desk operations, which employ 160,000. Another 260,000 software professionals are estimated to work in what NASSCOM calls user organizations.

${ }^{4}$ Note, however, about two thirds of all software occupations are not in the IT sectors. Thus, the true number of software workers in the U.S. is probably closer to 3 million (see also IT Workforce Update, 2003).

${ }^{5}$ It is likely that in these countries, the true size of software production is even higher since a large number of firms not in the software business, such telecommunications, banking and finance, and large retail and banking firms produce significant amounts of software for their internal use.
} 
Table 1 also shows that in Brazil and China software sales are between 1and $1.5 \%$ of GDP, only slightly smaller than the corresponding figures for richer countries such as the U.S., Japan and Germany. ${ }^{6}$ The software share of GDP is higher in Israel (3.7\%) and India (2.5\%). The shares for India and China have also increased substantially in recent years, while they have remained more stable for the other countries. In 2001 the GDP share of software was only $0.6 \%$ in China and $1.7 \%$ in India. Thus, in these two economies software has continued to grow faster than GDP in 2001-2002, despite the general slowdown in the IT sector worldwide. Moreover, in all five countries, software ranks high when compared to their overall level of development, as measured by the ratio between the software share of GDP and the GDP per capita (Botelho et al, 2005). In all the five emerging countries these ratios are far higher than the U.S., Germany, and Japan, suggesting a specialization in software. The level of the index is particularly impressive for India (about 10-20 times higher than the US, Japan, and Germany).

But the most impressive figures about the software industry in these emerging economies are their growth rates, which have ranged as high as $40 \%$ per year in the Indian case (table 2, column 2). The number of firms has grown as well. In India, the membership of NASSCOM increased from around 100 in 1990 to 797 in 2000 (Athreye, 2005). Similarly, the number of new Irish software firms increased from less than 300 in 1991 to 760 in 2000 (Sands, 2005). Botelho et al (2005) report that of a sample of 685 Brazilian software firms in existence in 2001, a little less than a third (210) were founded between 1996 and 2000, and a slightly larger fraction, 221, were founded between 1991 and $1995 .^{7}$

\section{TABLE 2 ABOUT HERE}

\footnotetext{
${ }^{6}$ The GDP shares of Brazil, China, and the domestic Irish software industry are indeed higher than other G7 countries, like the UK ( $1 \%)$ or Italy $(0.8 \%)$, and they are comparable to the figure for the G7 countries as a whole. ${ }^{7}$ There are no specific figures for the creation of new software firms in China or Israel. However, the existing scattered accounts support the idea of high rates of entry into the software industry in both countries.
} 


\section{Potential Determinants of the Success Stories}

\subsection{Export-led vs. Development-Led Export Model}

There is one noticeable difference between the growth patterns of the 3Is vis-à-vis China and Brazil. As Table 2, column 3 shows, the export shares of the 3Is are far higher than for China and Brazil. ${ }^{8}$ However, the export share in China has grown substantially from about 5\% in 19992000 (Tschang and Xue, 2005) to $11 \%$ in 2002. In China, and perhaps in Brazil as well, exports are based on competencies nurtured and developed by serving the domestic market (cf. Botelho et al, 2005).

Even among the 3Is there are differences in the extent to which the underlying growth model is export-led $v s$. development-led. As figure 1 shows, although the export shares for the three are converging in the late 90 s, the starting points differ greatly. In the Indian software industry exports were a large share of sales from the early 1990s. In 1993, the first year for which Athreye (2005) reports export and total sales data, the share was 59\%, whilst in 1991 it was $41 \%$ for the domestic Irish industry and $20 \%$ for the Israeli industry. As Breznitz (2005) notes, the Israeli industry was catalyzed by domestic demand and became an international player only later on. Although the leading Irish firms have been export oriented from the beginning, the growth of the Irish industries owes a great deal to the activities of MNCs who located a variety of software operations in Ireland.

\section{FIGURE 1 ABOUT HERE}

The Indian software industry is perhaps the clearest example of export led growth. The impetus for growth initially took the form of the on-site model, in which the Indian firms (and

\footnotetext{
${ }^{8}$ As shown in Sands (2005), the software MNCs in Ireland exported 95\% of their sales in 2002, and this percentage has been largely above $90 \%$ since 1991 .
} 
many U.S. based firms as well) literally rented out software programmers to work at the client's site and under the client's management. India based firms enjoyed a clear cost advantage over their U.S. rivals in the lower end of software services, and did not compete directly with market leaders such as EDS, Computer Science Corporation, Anderson Consulting (now Accenture) and IBM. With booming demand, Indian firms had the opportunity to learn how to manage relatively large projects. Euro conversion projects and Y2K projects were well suited for the kind of competences and skills that the Indian software industry had by then developed.

The domestic Irish industry shows a less pronounced initial dependence on exports. Sands (2005) argues that MNCs were an early source of demand for domestic software firms. As also discussed in Arora, Gambardella, and Torrisi (2004), many successful Irish software firms started as programming houses for the subsidiaries of the MNCs in the information technology (IT) sector, or as software application developers for other non-IT firms, whether Irish or foreign-owned. Interviews with several Irish software firms indicated that they saw the MNCs both as a source of revenue and as providers of access to foreign markets.

Of the 3Is, Israel relied the least on the export market at the outset of its software industry, which makes this country the closest among the 3Is to the development-led export model. Breznitz (2005) argues that "the rapid expansion of defense R\&D and the fast accumulation of IT skills by both university graduates and graduates of the military technological units created both local demand for IT usage, the knowledge base to supply it, and a positive attitude toward this nascent industry." In addition, the Israeli software industry sits on the shoulders of a giant. It is linked to the sizable Israeli IT hardware industry $(55,000$ employees in 2002), a source of both demand and expertise.

The latter point is important. Apart from India, which started internationally from its 
very outset, in all the other countries the software industry grew out of links with related sectors that were the sources of competencies and provided the underlying demand as well. For example, banking and telecommunications, along with customer electronics and retail automation, have been the principal sources of domestic demand in China. The government has been another big player, with national and regional governments often favoring domestic vendors for a variety of PC based software, from the operating system to application software. ${ }^{9}$ Domestic demand also explains why Brazil, rather than for example some of its neighboring regions, has become an important software producer. Brazil has an uncommonly high share of IT expenditures on GDP. World Bank data cited by Botelho et al (2005) indicate that in 2000 Brazil spent $8.3 \%$ of its GDP on IT. This compares to $7.9 \%$ in the U.S., $7.4 \%$ for Israel, $5.7 \%$ for China, and only 3.9\% for India. The Brazil figure stands out when compared to its neighbors Mexico (3.2\%) and Argentina (4.0\%). Lead users such as banks have been central to the growth of the Brazilian software industry. Similarly, the telecom industry pushed the demand for communication software (e.g. the growth in the demand for cell phones). Public sector demand, exemplified by the installation of an electronic voting system, also helped (Botelho et al, 2005)

\subsection{Human Capital and the Supply of Skills}

One regularity among the 3Is is that they exhibited an "excess" supply of human capital in the 1980s and early 1990s, and specifically, an excess supply of engineering and technology graduates. The 3Is are not the countries with the largest proportion or even number of science and engineering graduates. Rather, the excess supply was relative to the demand from manufacturing and related services. Simply put, the 3Is have produced more engineers than their

\footnotetext{
${ }^{9}$ For example, Saxenian (2003) reports that the Beijing municipal government and the Guangdong provincial government recently required that all their departments used a Chinese language office software package, WPS2000, rather Microsoft Office2000, in spite of its lower technical quality.
} 
hitherto lackluster industrial sector could absorb. ${ }^{10}$ This is particularly relevant from about the mid 1970s up until the late 1980s. During this time, these countries grew only modestly, while continuing to invest in science and engineering. Indeed, the average growth rate of GDP per capita for India between 1970 and 1990 was barely 2\% per annum, while both Israel and Ireland managed to grow at $2.4 \%$ and $2.9 \%$ respectively. In all three cases, however, this performance is lower than the performance of peer countries. Moreover, it masks the large decadal variation. In India, the 1970s were a period of very low growth, while the 1980s could be called the lost decade for both Israel and Ireland, a feature is which also reflected in the migration patterns to the United States, as discussed in section 5 below as well. ${ }^{11}$

In the more advanced countries and the rapidly growing Asian countries such as South Korea, Taiwan and Singapore, the science and engineering graduates faced a high opportunity cost of working in the software sector. Plentiful job opportunities in industry, in well established firms with good opportunities, mean that there would be fewer entrepreneurs setting up software firms, and nascent software firms would find it difficult to attract talented engineers.

Why the 3Is were abundant in technically skilled workers is not well understood, but there is no doubt that having such abundance was crucial for software success. There are two issues here. The first one has to do with the level of supply of the relevant human capital. The other issue is about the elasticity of the supply of graduates in the countries that we are studying. The education institutions in all five countries have responded with sizable increases in the

\footnotetext{
${ }^{10}$ In the Israeli case, the economic crisis in early 1980 s and with the growing military alliance with the U.S. after the 1973 war led to a significant downsizing in the defense industry, the most notable instance of it being decision to stop the development of the latest fighter-jet ("The Lavi"). The result was that thousands of highly trained and experienced engineers became available. Breznitz (2005) also notes that generous redundancy packages became seed capital for many of these would be entrepreneurs.

${ }^{11}$ A regression of the stock of scientists and engineers on per capital GDP and other factors (not reported here) showed that the 3 I countries all had actual stocks that were higher than the predicted stocks of scientists and engineers.
} 
number of graduates as the demand for their services rose over the 1990s.

Accredited engineering capacity in India increased from around 60,000 in 1987-88 to around 340,000 in 2003, and IT capacity has increased from around 25,000 to nearly 250,000. It is likely, however, that actual number of IT admissions increased more slowly and the number of IT graduates increased even more slowly. NASSCOM figures indicate that in India the number of number of IT graduates increased from 42,800 in 1997 to 71,000 in 2001. By comparison, the number of IT graduates in the U.S. increased from 37,000 in 1998 to 52,900 in 2000. During this period the IT workforce (which does not directly correspond to IT degree holders) in the U.S. was probably eight to ten fold larger than the IT workforce in India.

Other countries report a similar pattern. Tschang and Xue (2005) report that in China the number of IT graduates increased from 29,000 to 41,000 in 1999-2001. Botelho et al (2005) note that the 18,000 graduates in IT in Brazil in 2000 is a greater per capita number than China and India. The latest OECD figures show that Ireland, with 34,000 graduates per year, now has the third highest share of adult population with tertiary degrees $(30 \%$ of which are in science and technology), after Canada and the U.S.

Such increases were accomplished through a mix of private and public efforts, with the mix varying across countries. In Ireland, Israel and China, the bulk of the efforts were probably in the public sector. Table 3 shows that Ireland differs markedly from comparable European countries such as Greece and Portugal in investing a much larger share of EU funds in human rather than physical capital.

\section{TABLE 3 ABOUT HERE}

In India, a substantial fraction of additional engineering capacity created during the 1990s 
was created in the private sector. Figure 2, which is based on data from the All India Council on Technical Education show that the nearly $80 \%$ of the accredited intake capacity for engineering students at the undergraduate level in 2003 (about 340,000) was in privately financed colleges (those that did not receive grants from the government). The role of privately financed colleges, the vast majority of which were created in the 1990s itself, is even more marked if one looks only at IT related engineering programs. Such a rapid expansion of engineering training capacity has raised valid concerns about the quality of the education and a variety of other social costs. Nonetheless, this supply response does speak to the flexibility that is rare in more advanced countries, and also speaks to the perceived returns on human capital.

\section{FIGURE 2 ABOUT HERE}

\subsection{The "Diaspora"}

One peculiar, but crucial element of the picture has been the role of human capital flows. In addition to the human capital "embedded" in exports, the 3Is, but China and Brazil as well, have directly supplied human capital, particularly to the U.S. As a result, all the countries have a substantial Diaspora in the U.S. Unlike the embedded variety, the direct exports have different fiscal and economic welfare implications.

A recent set of estimates provided by Carrington and Detragiache (1998) indicate that the stock of high skilled (more than 13 years of schooling) immigrants in the U.S. from China, India and Brazil were about 400,000, 300,000 and 60,000 respectively. ${ }^{12}$ Kapur and McHale (2005) show that China is the second country after India ranked by the number of approved H-1B visa

\footnotetext{
${ }^{12}$ Brazilian emigration of skilled workers, though lower in absolute volume, when expressed as a percentage of the stock of skilled population, are comparable with India and China. Unfortunately, the small absolute size of the stock of Brazilian immigrants in the U.S. has meant that little is known about their role in the growth of the Brazilian software industry.
} 
petitions by the U.S. Immigration and Naturalization Service (INS). Indians alone account for more than $42 \%$ of all the H-1B visas approved in this period, over half of which went for computer related occupations. Independent estimates of the U.S. IT workforce indicates that more than $15 \%$ of this workforce is from Asia, of which slightly less than $1 / 3^{\text {rd }}$ are from India, implying that Indian born account for about 5\% of the IT (mostly software) workforce of about 3.2 million (IT Workforce Update, 2003).

The Diaspora can provide links, act as "reputational intermediaries", and upon returning, can bring back valuable skills and expertise. Despite much talk of IT professionals returning to India and China, only in Ireland the return of skilled emigrants has clearly increased the domestic supply of skilled people (Kapur and McHale, 2005). Similarly, Sands (2005) survey of 58 Irish software entrepreneurs indicates that $66 \%$ of the founders of the Irish software firms in her sample had worked abroad, $55 \%$ had worked for multinational companies, and $74 \%$ of her companies had one founder who worked abroad, largely consistent with earlier findings (O’Gorman et al, 1997).

The Israeli case is similar to India. There is little evidence of systematic returns of immigrants to the U.S. At the same time, there is no evidence of major skill shortage in Israel. The number of U.S. PhDs awarded to Israeli nationals has remained stable since the early 1990s, while the same time, the number of $\mathrm{PhD}$ students who plan to stay in the U.S. have increased slightly from $51 \%$ to $57 \%$, albeit well below the corresponding figure for Indian and Chinese $\mathrm{PhD}$ recipients in the U.S., which tend to be around 5-10\%.

Despite the many potential benefits of a Diaspora, the outflow of skilled engineers, scientists and doctors does represent a net loss of talent and of the considerable investment in training the emigrants. The broad question about the net effects of the international mobility of 
skilled people on the home country is a complex one and well beyond the scope of this article. However, Kapur and McHale (2005) conclude that the benefits from the Diaspora outweigh the costs for the three Is for the development of the software industry. In other words, setting aside the question whether the brain drain represented by the Diaspora was a good thing or not, the software industries of India, Ireland and Israel certainly benefited from having a Diaspora. Given the domestic market orientation of software industry China and Brazil, the tradeoff has likely been less favorable.

\subsection{Multinational Firms}

One potential success factor, even though sometimes controversial, that is often highlighted in analyses like ours is the role of the multinational firms (MNCs henceforth). MNCs have been a sizable presence in the software industries of our countries. At the risk of some exaggeration, one can say that MNCs came to Israel to do R\&D, to India for inexpensive skilled workers, and to Ireland to leverage tax incentives and access the European market. ${ }^{13}$

Giarratana, Torrisi and Pagano (2005) show evidence of these different patterns. They show that in Ireland the entry of the IT MNCs precedes the rise of the domestic software industry. About $57 \%$ of the ICT MNCs that are present in Ireland today entered the country before 1990. This compares to $44 \%$ in India and 37\% in Israel. The difference between Ireland and the other two "Is" is even more marked if one looks only at the software MNCs. The shares are $55 \%$ for Ireland, and they drop to $18 \%$ and $16 \%$ for India and Israel. Giarratana et al (2005) find that while in Ireland the MNCs have contributed to the initial push of the industry, it is in Israel that today one observes a more active set of alliances and similar linkages between MNCs

\footnotetext{
${ }^{13}$ In time, they also established software development and R\&D facilities in Ireland. Of course, India is too large a market to ignore for software products and so firms like Oracle and Microsoft also came to sell in India.
} 
and domestic software companies, in marked contrast to India. Giarratana et al also find that two-thirds of the existing ICT Irish patents assigned to local MNCs were granted before 1994, against 37\% for Israel and 32\% for India, which suggests that the MNCs have begun to invest in R\&D more recently in Ireland and India as compared to Israel. ${ }^{14}$ This is consistent with the view that in Ireland the MNCs played an important role in nurturing the rise of the domestic firms when the industry started. By contrast, in Israel and in India there seems to be a co-evolution of the entry of MNCs while the industry grew in the 1990s.

The available evidence also suggests that the MNCs, especially Siemens and Ericsson, are contributing to the formation of domestic competencies in Brazil (Botelho et al, 2005). As in Brazil, the list of the top 10-15 software companies in China include MNCs like IBM, Microsoft, Oracle and SAP. These firms play a major role in the national industry especially as suppliers of their packaged products, but their role in developing local competencies is less well understood.

\section{$4 \quad$ Has the Growth of the Indian Software Industry Been Good for the U.S.?}

To understand the impact of the rise of the emerging Indian software, one must understand the nature of software engineering. Specifically, software engineering work can be decomposed into separate elements, and, at least at a technical level, there is no necessary requirement that theses elements are performed by engineers with the same firm or even in a given location. This basic insight about the nature of this technology results in two important observations. First, while there has been rapid growth in export-oriented software in these countries, the bulk of export-oriented activities have involved software activities that are (a) complementary to value-added activities done in the U.S. and (b) at a "lower level" of the value

\footnotetext{
${ }^{14}$ Giarratana et al (2005) confirm the stronger linkages between domestic and multinational ICT firms in Israel by using patent citation data. There are more cross-cites among the two types of firms in Israel than in the other two countries.
} 
chain (e.g. maintenance rather than initial product development). Second, though early attempts to establish an international division of labor in software have focused on software products and services that are likely easily decomposable, the next generation of contracts is much more likely to involve a higher level of integration between firms and locations. As a result, it should not be surprising if Indian software firms start to establish facilities in the U.S., and that leading U.S. firms begin to locate at least some high-level engineering work in emerging economy establishments. The remainder of this section develops our basic insight about product modularity more carefully, and then draws out the implication for the impact of these factors on economic development in the U.S. and emerging economies. Since outsourcing to India is the most significant in terms of employment, we focus on the Indian case to exemplify our argument.

We shall not enter the debate on whether the current job losses due to growth in software production overseas will be quickly made up by the creation of new opportunities at home. In our view, this debate echoes earlier debates that appear to pit free trade against job losses in existing industries. The conclusion of most mainstream economists, with which we broadly agree, is that although free trade creates winners and losers, the gains are greater than the losses, and thus, if the winners were able to compensate the losers, free trade ought to be supported. In this instance, we think that policies, such as retraining, which ameliorate the impact of such job losses, are a good idea. ${ }^{15}$ It is also worth pointing out that the total Indian software workforce engaged in exports (estimated to be less than 400,000 ) is still a small fraction of the more than 3.2 million software professionals in the U.S. Indeed, it is conceivable that the business cycle and technical progress in software technologies, which are making possible the automation of a

\footnotetext{
${ }^{15}$ On the debate about the outcomes for the U.S. of the outsourcing game in software and IT more generally, see for instance Mann (2003) and the McKinsey Global Industry Report (MGI, 2003).
} 
variety of tasks, such as some aspects of network and database administration, and testing and code reuse, are more potent in this context than the growth of the Indian software sector.

Thus our focus is on a related question. Suppose that the free trade is superior in that the U.S. is relinquishing activities that are becoming commoditized, in which the U.S. no longer enjoys a comparative advantage. Some observers have speculated that this process will lead to Indian software industry become more sophisticated and productive, so that the current set of activities in which the U.S. currently dominates, namely those intensive in design and innovation, will also be lost. A more extreme version of this view is that R\&D follows manufacturing, so that the offshoring of manufacturing will quickly lead to R\&D activities also moving offshore. Might therefore the offshoring of software coding and maintenance cause it to be soon followed by the more design intensive activities as well? The answer is simple. Such a succession is neither quick nor is it inevitable. Indeed, there are strong reasons to believe that the U.S. will remain the center of software innovation for the foreseeable future.

Though it is not easy to find the analogue of "production" in software, one can roughly divide software related activities into design, coding and maintenance. Subject to the usual caveats when one draws such sharp contrasts, one can think of coding and maintenance as analogous to "production". Much (though not all) of the software related activity being carried out in the emerging economies is of the sort that complements the activities carried out by software firms, substituting for the most part activities carried out by the user sectors. For instance, NASSCOM figures indicate that the three largest industry "verticals" in terms of the share of export revenues for the Indian software industry are Banking, Finance and Insurance (35\%), Manufacturing (12\%) and Telecom (12\%). ${ }^{16}$ Though at variance with the common

\footnotetext{
${ }^{16} \mathrm{http}: / /$ www.nasscom.org/artdisplay.asp?cat_id=314 last viewed on 2 May, 2004.
} 
perception that the software industry in India is the result of outsourcing by U.S. software firms, the result should not be surprising. Software is a general purpose technology, with the result that user sectors account for a very substantial portion of software production. For instance, the latest available data from the Bureau of Economic Analysis shows that of the 3.2 million IT workers (including programmers, network administrators and IS managers), only about 1 million worked in the software industry itself. Thus, nearly $2 / 3$ rds work in the rest of the economy, especially insurance, banking and finance.

In this sense, much of what is being offshored to India is the production of software, rather than its design. We have already noted the low revenue per employee in the Indian software industry, approximately $25 \%$ of that in the U.S. industry. Other evidence points in the same direction as well. Arora et al (2001) cite evidence from interviews with Indian software firms between 1997 and 1999 and find that porting existing applications from mainframe to client server, maintenance and enhancement of existing applications are examples of typical activities. The typical projects were small and technically undemanding (and responses to a survey of Indian software firms indicated that the "most important project" in 1998 had a median size of 150 man months). Since then, the activities have become more sophisticated and larger in scale (Athreye, 2005). However, requirements analysis and design, not to mention creation of new products and "solutions" is still mostly the province of the U.S.

If India is taking up mostly production and maintenance jobs, while leaving the more innovative segments of the industry to the U.S., we then have to understand the implications of the physical separation of these two activities. Note first that in many industries the locus of production and the locus of invention are physically separated. This is particularly true when the body of knowledge underlying the invention process has a strong scientific basis. Building on 
earlier work by Lamoreaux and Sokoloff $(1996,1997)$, Sutthiphisal (2003) studied the location of production and invention in three different industries during the Second Industrial Revolution, viz. textile, shoe, and the electric industry. He finds that in general the locus of invention did not shift with the locus of production as the latter moved to other locations. Moreover, he finds that the link between location of production and invention is weaker in the more "science-based" electric industry. Using data from a century later, Mariani (2001) studies the location of R\&D and production facilities by the Japanese MNCs in Europe. She finds that in low and medium R\&D industries, R\&D labs are more likely to be located close to production facilities, than in more R\&D-intensive industries.

A physical separation between the design intensive and production activities comes with its costs, including transaction and contracting costs, and communication and management costs. Physical separation may reduce the potential learning from production (e.g., Arrow, 1962, Enos, 1962) or from feedbacks and linkages emphasized by Kline and Rosenberg (1986). Nonetheless, the lower cost of labor and the ability to work around the clock are important offsetting features. Perhaps the least appreciated benefit is the greater project management and delivery ability of Indian software firms, which they have acquired over the last decade. Competition among Indian firms has meant that the benefits have accrued largely to the customers of Indian software firms, that is to say, to American firms. This point is obvious when stated insofar as it is a benefit of free trade. Less obvious is the implication that firms from countries such as Japan, Germany and France benefit far less. Since the principal competition for U.S. firms is still from these countries, there are important strategic benefits as well. Simply put, by outsourcing, U.S. firms are gaining important advantages over European and Japanese competitors in terms of lower costs, greater flexibility, and shorter product development cycles. 
With globalization of production, it is perhaps inevitable that competing regions and countries will be able to learn and improve their productivity and challenge the leader. The leader must make sustained investments in innovation. Evidence about these patterns is offered by the long-run history of the U.S. chemical industry. The U.S. chemical industry grew through technology borrowed mainly from Germany and the U.K. The Second World War and the shift from coal to oil based feedstocks marked the rise of the U.S. as the technology leader, albeit some time after it had emerged as the leading chemical producing nation. Over time, chemical production has grown elsewhere, particularly in the economies such as Taiwan and Korea, and since the 1980s, China and India and the Middle East. Moreover, as discussed in Arora and Gambardella (1998), the U.S. chemical industry has developed since the 1950s an independent sector of specialized engineering firms (SEFs) that supplied new process technologies via licenses and chemical process engineering services to the rest of the world. In so doing, they were nurturing the international competitors of the U.S. chemical firms as much as they were nurturing the U.S. chemical companies. ${ }^{17}$

Can the U.S. specialize and keep its comparative advantage in the higher end? The starting point for this discussion is to note that there are two key resources required to remain the center of innovation in software: access to talented designers, software engineers and programmers; and proximity to a number of large and technically sophisticated users. The U.S. dominates on both counts.

As noted in the earlier section, emerging software producing regions are leveraging their abundance of relatively underused human capital, especially of engineers and IT professionals.

\footnotetext{
${ }^{17}$ Moreover, even if the U.S. chemical suppliers may have been hurt by the international diffusion of technology, U.S. engineering firms and contractors have benefited. Indeed, the U.S. is still the world leader in the provision of chemical process technology and engineering services.
} 
The U.S. also produces abundant human capital. But that is not all. The very same processes of globalization that have led to the growth of software overseas have also worked to attract the best and brightest to the U.S. Thanks to the size and the openness of its culture and economy, the U.S. has had no difficulty in attracting talent, providing it with a strong advantage over potential competitors such as Japan or Western Europe.

Even more prominent is the relationship with the users. New software applications depend largely on knowledge about demand, and about the use of the applications. This is apparent for example in telecommunications and semiconductors, where the software that is needed to design the chip is part of the product itself. More generally, a substantial fraction of software is used for running businesses and business processes. Hence, proximity to business activities is crucial for innovation in this industry, which consists of solutions to emerging business problems, often specific to particular industrial sectors, such as banking, finance, and retail, as well as telecommunications and manufacturing. Indeed, the development of new commercial applications or "solutions" is a very special comparative advantage of the U.S. India's economy is growing, and we expect that sophisticated domestic demand for software will eventually rise in India. At present, however, the U.S. lead is overwhelming.

Moreover, as was true of human capital, globalization may reinforce this lead, because we find that innovative companies from Israel, Ireland and even India are likely to move their operations to the U.S., to be closer to their users. Sometimes venture capitalists push for such as move as well. Indeed, although firms do not have to be based in the U.S. to tap its equity markets, a strong presence in the U.S. does help a great deal. Similarly, other intermediating institutions such as legal services and thick and well functioning labor markets are other important sources of advantage that the U.S. enjoys, which are not likely to be eroded soon. 
There are, of course, counter tendencies as well. Insofar as Indians have a preference for staying in their home country, the cost of scientists and engineers will be lower in India, so that the cost of R\&D activities that are human capital intensive and relatively less intensive in physical infrastructure will be lower. There is anecdotal evidence that India is being viewed as an attractive location for certain types of R\&D activities, although anecdotal evidence also suggests that U.S. firms are not locating mission critical activities in India, nor are they moving activities at the technological frontier.

\section{$5 \quad$ Is the Globalization of Software Good for India?}

The other natural twist of the question that we asked in the previous section is whether the growth of software, and particularly, its globalization, has had net benefits for India. ${ }^{18}$ In addition to the standard benefits from specialization according to comparative advantage, one must also reckon the benefits from increasing returns to scale and from possible productivity increases as Indian firms learn and gain experience. In this respect, it was a crucial strategy for India to specialize in activities wherein it was complementary with the international industry. If India had instead moved up quickly onto higher value added products, as many had suggested, perhaps because of the common belief that moving up the value chain is only way to sustain an industry, it would have most likely conflicted with the U.S. Ireland and Israel did face this problem, especially during the downturn of the international IT demand after 2000. Because software product development was more important in these countries than in India, it was natural that the reduced international demand for IT had a bigger impact on them. Indeed, as shown in Arora and Gambardella (2005) the performance of the Irish and Israeli software industries faltered in 2001-2002, with reduced profitability and employment for the first time since the

\footnotetext{
${ }^{18}$ Once again, we focus on India for brevity and emphasis.
} 
early 1990s. By contrast, the growth of the Indian software industry slowed but only to about $20 \%$ per year in this period.

To summarize, the opportunities created by the international demand, India has had obvious benefits from its rising software skills. First and foremost, the growth of software has contributed in a non trivial way to the growth of the country as whole. Moreover, the growth of the software industry has provided the basis for the growth of a new entrepreneurial model, which has in turn had spillovers for related activities, such as business services and even some type so R\&D tasks.

However, there is one feature that provides pause for thought, namely the observed patterns of international migration of human capital. As Table 4 shows, the number of Indian born resident in the U.S. increased nearly three fold between 1990 and 2000, with over 80\% of the Indian born residents having tertiary level education. Brazilian and Chinese born residents have lower levels of tertiary education than for Indians, but still above 50\%, and have also increased rapidly in the last decade. To put these figures in perspective, around $50 \%$ of the native born adult population in the United States has tertiary education, second only to Canada.

\section{TABLE 4 ABOUT HERE}

Such large scale migration of human capital has conflicting welfare implications. To the extent that the increase in the U.S. labor supply curbs the U.S. wages, native born workers have lower welfare than would obtain without international labor mobility. By contrast, the Indian workers gain because the salary of the emigrants increases as does the salary of the workers who stay in India (or at least it does not fall as much as it might have given the large increases in the supply of Indian IT workers). The standard argument, however, also implies that because the migration follows more productive opportunities in the U.S., the re-allocation of Indian workers 
to the U.S. implies a higher combined output of the two countries than if migration did not take place. Hence, proper redistribution policies, or the extent to which Indian workers ships some of their rents back to India (e.g. links to Indian software companies, returnees, consumption of other Indian commodities), may in the end enhance the overall value for India as well.

Yet, if there are externalities in software production, due to spillovers or scale economies, associated with the agglomeration of human capital, the picture could be very different. Such externalities are plausible in activities like software. With externalities it is possible that as more Indian IT engineers flow to Silicon Valley or other U.S. locations specialized in IT, the productivity of these workers may even increase, at least until congestion effects overwhelm them. The increase in productivity would then encourage more migration from India. In addition, if the Indian industry suffers from reduces spillovers or lower scale economies, due to the outflow of skilled workers, Indian software salaries may not rise fast enough to match U.S. salaries. This may imply persistence differences in salary that feed a continuous outward flow of software professionals from India to the U.S. ${ }^{19}$

However, the available evidence suggests that in fact Indian software salaries have increased faster than those in the U.S. Athreye (2005) presents data which suggest that whereas U.S. salaries for a variety of software occupations such as programmer, project leader, quality assurance specialist and systems designer increased by about 21\% between 1995 and 1999, Indian salaries increased by nearly $45 \%$.

\footnotetext{
${ }^{19}$ The problem would be even more severe if there is some sort of selection, that is, if those who move are the more productive workers who can take greater advantage of the opportunities that open up in more advanced nations. Indeed, this is the problem faced by Europe today, whose brain-drain to the U.S. does imply a possible deficit of highly skilled people. Yet, a major difference between Europe and India is that India can produce human capital at a substantially higher rate, in large measure because of a much younger population, so that India can sustain a net outward migration for much longer.
} 
In sum, while the migration of Indian talents to the U.S. can be a problem for India if there are externalities involved in these activities, it is India's ability to sustain a continuous flow of human capital that may turn this into a major opportunity. As people move, but they are replaced by new workers, while, the flow of workers to the U.S. feeds its software industry with talented programmers and motivated entrepreneurs. Indeed, it may well be that the main Indian (or Chinese) resource, could be its academic system, supplying human capital to the world.

\section{Software: A Model for Other Emerging Economies?}

The spectacular growth of software in India, Ireland, and Israel raises the natural question whether other developing countries can take up a similar opportunity. We believe that potential emulators will likely find it difficult to replicate two central features of the successful growth of the software industry in the 3Is: The excess supply of skills and the international connections.

Software is labor intensive but it does require skilled and trained labor. Indeed, in software, there is very little use of workers with modest education and training, in marked contrast to large scale manufacturing operations. Most developing regions have abundant labor, but rarely abundant skilled labor. Not only could this hamper the growth of a software industry, such a growth may even increase inequality by greatly increasing demand for the small segment of the population of the highly skilled and educated, and leave virtually untouched the rest. Indeed, the growth of the software industry draws away skilled engineers from other sectors. This may not only increase inequality, but may also reduce rather than increase total output if the growing middle class incomes are primarily directed at imports (e.g. Gambardella and Ulph, 2003).

There are several non G-7 countries with substantial number of underemployed college 
graduates. However, few are English speaking countries with a Diaspora or other means of linking to their potential export markets. Therefore, it is unlikely that others can replicate a success of similar proportions, even more so because they would be playing catch-up.

Nonetheless, there are a few regions in the world where software has thrived, even though not at the rates that we have observed for our 3Is. As discussed earlier, and in greater detail in Arora and Gambardella (2005) some other successful examples in software include Finland and South Korea. To a lesser extent, Hungary and the Czech Republic are also showing some signs of vitality in this area. Broadly speaking all these cases fit our model. They all have a relatively higher share of educated population compared to their level of development. At the same time, they do not have a wide and diversified industrial basis, which implies that the opportunity cost of these people to work in the software industry is not significant. At the same time, there are domestic sources for the formation of software competencies, like the electronics industry in Korea, the telecom leader Nokia in Finland, or some investments in ICT and electronics foreign firms in Hungary and the Czech Republic.

More generally, one can list the exportable lessons for other emerging economies. First and foremost, our cases have underscored the importance of openness. Export markets can facilitate scales of operation and opportunities for learning that would otherwise not be possible. However, as we have emphasized, openness means more than "Free Trade". It includes openness to MNCs. In Ireland, for instance, MNCs have been important as sources of demand and competencies, and in India, they appear to have helped in legitimizing India as a source of software. Doubtless, relying upon export markets also makes one more vulnerable to the vagaries of the business cycle and policies in those markets, policies over which one can have little control. Openness has other costs as well, as domestic firms may be squeezed out of 
learning opportunities and experienced managers and engineers may lured away to jobs in the developed countries, as in India or Israel. Such mobility of people, which is an important component of openness, can however be turned into an advantage because ethnic links often underpin important trade links (e.g., Rauch, 2001), and in a human capital intensive industry such as software, such links are vital. If conditions are right, some of the emigrants may also return, as was the case in Ireland, bringing with them valuable skills and experience, both technical and managerial.

A second exportable lesson is that the "upgrading" to overcome the inevitable erosion of initial competitive advantage can take many forms. In particular, it does not have to take the form of moving up the technology ladder. For instance, many observers of the Indian software industry have noted that with the growth of the industry the advantage of low wages would decline. Many even characterized the growth of the Indian software industry as unsustainable unless firms began to invest in R\&D to undertake sophisticated product development. The prescription that emerged was that Indian firms would have to move rapidly from merely performing programming to "higher value" activities such as design and product development (e.g., Heeks, 1996; DaCosta, 1998). ${ }^{20}$ Such recommendations are often part of a broader mindset wherein progress in technology intensive industries must necessarily take the form of moving up the technology ladder, to parallel (if not imitate) the activities undertaken in the rich countries.

\footnotetext{
${ }^{20}$ Frequently, this recommendation was accompanied by a complementary recommendation for firms to focus on the domestic market, which would provide the initial demand for more sophisticated products and services. Arora $e t$ al. (2001) conclude that the competencies developed in the domestic Indian market were not helpful for exports. Athreye's study of CITIL (now i-Flex), a Citibank subsidiary, indicates that the Indian market could provide a fruitful learning base for products (in this case, a backend banking product) that could be successfully exported. The study also makes clear, however, that this strategy depends on a number of concomitants for its success. In this case, Citibank's own internal use of the product (albeit in India and other developing country markets) provided important legitimization. Further, CITIL's strategy was to initially focus on other developing country markets, particularly in the British Commonwealth, avoiding head to head competition with incumbent producers in developed countries, most of which were not large established firms. Only after succeeding in other export markets did CITIL enter the developed country markets.
} 
Indeed, policy makers in developing countries often point with pride to the technological accomplishments achieved in their countries, treating them as indicators of success.

Considerable pride is staked on the formation of national champions and the ability to undertake high-tech projects and produce technically sophisticated products, regardless of their commercial feasibility.

The lessons from the Indian experience are the opposite. To be sure, in recent years the leading Indian firms have managed to take on a larger range of activities. But, for the most part, developing new products or undertaking high level design has not been the principal means of offsetting the wage advantage. Rather, Indian firms upgraded their ability to take on and manage larger projects. Instead of moving aggressively into product design, they focused on taking on lower end functions such as maintenance and support. This strategy also fits theoretical models of the advantages from international trade as the one by Gomory and Baumol (2000). In this respect, although not as lucrative, the lower end activities undertaken by Indian firms involve a steady and predictable stream of revenues since maintenance contracts are typically three to five years in duration. Moreover, this focus leveraged the capabilities Indian firms had developed, which was to manage projects with large teams of skilled people.

Conversely, most of the early forays of Indian software firms into product development did not pay off. We do observe other Indian software firms, mostly later entrants that do not have the same possibilities in software services, investing in developing products for targeted niche markets as a means of differentiating themselves. Some of these are likely to succeed. However, even if they fail, it is unlikely to shake the foundations upon which the Indian software industry has grown. 
This also speaks to the development-led export model of Brazil and China. Growth based on domestic demand can give rise to development processes that help firms move down their learning curve, even though the drawback of any strategy that relies too strongly on the domestic market is that there can be too narrow a focus on the idiosyncratic needs of local users, as the Brazilian case suggested. The Chinese strategy, which is essentially one of import substitution, is even less promising in terms of the export markets in the West. It may, however, prove of some value in terms of the East Asian export markets of Japan and Korea.

Finally, our case studies highlight the importance of entrepreneurship. In each of the countries, firms have sprung up to exploit the opportunities opened up by the growth of demand for software. However, these firms have not arisen in a vacuum. Frequently, related industries such as IT, telecom and hardware have supplied the entrepreneurs and managers. In some cases, particularly in Ireland and India, nationals working and trained overseas have played an important role as well. For countries wishing to develop their own software industry, a key question to whether they have the related industries to act as the nurseries for future software entrepreneurs and managers.

But our studies also provide a message of hope in this regard. For India and Ireland, and to a lesser extent for Israel, entrepreneurship in high tech industries had hitherto been the exception, not the norm. These countries had mostly lacked a culture of risk taking that one takes for granted in the U.S. Financial institutions and capital markets were not set up to promote entrepreneurship, and there were few role models to follow. In India, commercial success had hitherto required preferential access to government permits and capital markets to exploit the protected India market. In Ireland, few believed that Irish scientists and engineers could develop and commercialize world scale technology until the Ionas and the Baltimores 
proved them wrong. Quite simply, the elasticity of entrepreneurship has proven to be high. For policy makers in developing countries this should be welcome news. What is required is not special programs to encourage entrepreneurship, but a clear opportunity, and an economic environment that minimizes legal barriers to entry and exit. For software, this welcome news must be tempered. Not only is the sustained boom of the 1990 s unlikely to repeat itself in the near future, even if such a boom arose, they would have to contend with established incumbents.

\section{$7 \quad$ Implications for Policy}

The previous three Sections hold specific implications for effective policy in both the U.S. and the emerging economies. The implications for U.S. policy are two fold. On balance, the rise of software services in emerging economies is a boon for the U.S. economy. Calls for restricting outsourcing are likely to harm the competitiveness of U.S. firms and reduce efficiency. However, since equity often sacrificed at the altar of efficiency in economic analysis, it is to stress that policies for mitigating the impact on software professionals is not only fair, but more importantly, upgrading the technical skills of the U.S. workforce is important also for sustaining the U.S. technological leadership. The U.S. leadership in technology has been based in some measure on access to skilled and talented people from the world over. In the short term, concerns over terrorism and anaemic job growth now threaten one of the most potent sources of U.S. advantage: Its open economy and culture. Though such threats are perhaps not severe and although the U.S. is likely to remain the primary destination for emigrants with training and drive (often educated at public expense in their home countries), policy must take account of the growing attraction of other economies. 
In terms of the emerging economies, our stories have shown the benefits of organizing policy to encourage economic growth based on the development of these types of industries around an investment in human capital, openness to international trade, investment, and competition, and domestic economic liberalization.

The implications for technology policy are more diffuse. Israel and Ireland are instances where enlightened government policy did help the software industry. Even here, the evidence for the efficacy of targeted sector specific policies is limited at best. Israel's software industry benefited from general support for R\&D and human capital development, and from the earlier growth of the computer hardware and electronics industries. The benefits of government venture capital funding and incubators are difficult to assess, and in particular, whether the benefits outweigh the costs. Ireland's welcome for foreign direct investment was aimed at boosting employment rather than promoting software. Software did benefit directly because these MNCs were initial sources of demand and as sources of competencies. We speculate that the indirect effects, including the training of managers and of legitimizing Ireland as a place to develop software, will prove to be more important.

The Indian case shows that a weak and inefficient bureaucratic structure works best when it attempts not to do too much. It also shows the virtues of decentralization. There is no doubt that competition among Indian states to develop software has kept political excesses in check and has focused government policy on addressing issues such as physical infrastructure instead of attempting to channel the industry into "high-tech" and "high value added" directions, or attempting to regulate entry and entrepreneurship. This is an instance also of the political economy of success - the success of the software industry has provided celebrity status for 
Indian software entrepreneurs and political clout to the industry, which the industry has used to push for sensible tax and capital market policies (e.g., Arora, Gambardella and Torrisi, 2004).

\section{Conclusions}

In the traditional neoclassical model, capital and labor are symmetric. Countries relatively abundant with labor can just as easily specialize in labor intensive sectors and adopt labor intensive technologies as countries with abundant capital can specialize in capital intensive sectors. However, as we all know, labor and capital have been anything but symmetrical. Poor countries have had to follow in the footsteps of richer countries, moving from agriculture to manufacturing, moving from labor intensive to capital intensive sectors. Might software, with its dependence on human capital but relatively low intensity in physical capital, offer a new way for labor abundant countries? Can developing countries leverage their abundant labor endowments to target human capital intensive service sectors for exports and growth, without having to invest the large amounts of capital that manufacturing requires?

It is true that software, particularly software services, do allow a country to participate in the high-tech sector with only a limited physical infrastructure. However, even a successful software industry is likely to account for a small share of GDP and employment. The software industries in the countries we have studied account for at best 2-3\% of their respective GDP, and an even smaller fraction of the total labor force, so that the direct impact on economic growth is likely to be small. Hence we turn to examine the indirect effects.

One possible set of indirect effects works through the links to other sectors. Some authors have argued that software is to the knowledge based economy what capital goods were to manufacturing - an input source whose importance for productivity and innovation was far 
greater than was reflected in revenues or share of GDP. Software does supply basic inputs to virtually every industrial sector. Better software would therefore increase productivity across the board. Though attractive, this argument has a problem. Software is internationally traded and it is not clear why a country, particularly not at the leading edge of technology, could not use software developed elsewhere. There may be some advantages to have a domestic software sector which could tailor software to local requirements at lower costs. However, this must be weighed against the possible lower efficiency in developing software domestically. The net effect of all these factors is that having a domestic software industry provides at best a modest contribution to the overall growth of the economy even when considering the potential effects on the large set of domestic user firms and industries.

Success at an export oriented industry also has spillovers for other industries in terms of enhanced reputation. China's initial success in producing and exporting light manufactures of all kinds has earned it the reputation of being a desirable location for all manufacturing. Conversely, years ago, Japanese automakers had to fight the reputation for shoddy quality that its early exports of light manufactures had earned it. Today, India enjoys a reputation for service quality, largely due to the software industry. It is no accident that it is the favored destination for other service exports, ranging from call centers, customer care and medical transcription to high end R\&D services.

We believe a more potent set of indirect effects work more subtly. Most of the successful software firms in the 3Is, in modeling themselves after their Silicon Valley counterparts, have also stressed shareholder value, and responsible and transparent corporate governance and accounting. Though American corporate governance is under attack, and with good justification, it is likely superior to the practices of the traditional firms in many developing economies, which 
frequently resemble family fiefdoms more than the shareholder owned corporations. The software industry can act as an exemplar of a new business model that features flatter organizations, individual incentives, competition, and export orientation, particularly for other sectors that rely upon skilled workers.

But perhaps most important of all, the success of an export oriented software industry can show to potential entrepreneurs what is possible with talent, luck and hard work. In Ireland, the success of the software industry provided others with the confidence that Irish high tech firms can compete with any in the world. In India, software was virtually the first instance where wealth was created honestly and legally, and more important, visibly so. Before this, wealth came either from breaking laws or at least bending them to one's convenience, using existing political and economic power. Partly as a result, commercial success had invited envy, cynicism and even outright hostility, and only rarely, admiration. While envy and hostility are not gone by any means, there is much more of admiration, and more importantly, a desire for imitation. Of course, entrepreneurs can only succeed if other conditions also obtain. Some of these, such as international links and supply of skills, are not easy to create. However, the task for any underdog region is probably easier today than at any other time in the past.

Policymakers in the U.S. should not view the growth of underdog regions with fear. Instead, the U.S. economy will broadly benefit from their growth. Over time, the growth of software and other high technology industries in these economies may raise other challenges. U.S. technological leadership rests in part upon the continued position of the U.S. as the primary destination for highly trained and skilled scientists and engineers from the world over. Though this is likely to persist for some time the increasing attractiveness of foreign emerging economy destinations is a long-term concern for continued U.S. technological leadership. 


\section{References}

Arrow, K., 1962, “The Economic Implications of Learning by Doing”, Review of Economic Studies 29: 155-173

Arora, A., Arunachalam, V. S., Asundi, J. and Fernandes, R., 2000, “The Indian Software Services Industry", Research Policy 30(8), 1267-1288.

Arora, A. and S. Athreye , 2002, "The Software Industry and India's Economic Development", Information Economics and Policy 14 (2): 253-273.

Arora, A., Gambardella, A., and Salvatore Torrisi , 2004, "In the Footsteps of the Silicon Valley? Indian and Irish Software in the International Division of Labor", in Building High-Tech Clusters: Silicon Valley and Beyond, Bresnahan, T. and Gambardella, A. (eds.), Cambridge University Press, Cambridge UK.

Arora, A., and Gambardella, A., 2005, "From Underdogs to Tigers", in The Rise and Growth of the Software Industry in Some Emerging Economies, Arora, A. and Gambardella, A. (eds.), Oxford University Press, Oxford UK, forthcoming.

Arora, A., and Gambardella, A., 1998, "The Evolution of Industry Structure in the Chemical Industry" in Arora, A., Landau, R., and Rosenberg, N. (eds) Chemicals and Long Term Economic Growth, John Wiley and Sons, New York.

Athreye, S., 2005, "The Indian Software Industry", in The Rise and Growth of the Software Industry in Some Emerging Economies, Arora, A. and Gambardella, A. (eds.) Oxford University Press, Oxford UK, forthcoming.

Barrett, A. and O'Connell, P., 2001, "Is there a Premium for Returning Irish Migrants," The Economic and Social Review 32 (1): 1-21.

Botelho, A.J. and Veloso, F., 2003, The Software Industry in Brazil-Strengthening the Economics of Knowledge, Softex (Sociedade Brasileira para a Promoçao do Software), Campinas, Brazil.

Botelho, A. J., Stefanuto, G., and Francisco Veloso, 2005, "The Brazilian Software Industry", in The Rise and Growth of the Software Industry in Some Emerging Economies, Arora, A. and Gambardella, A. (eds.) Oxford University Press, Oxford UK, forthcoming.

Bresnahan, T. and Gambardella, A. (eds.), 2004, Building High-Tech Clusters: Silicon Valley and Beyond, Cambridge University Press, Cambridge UK

Bresnahan, T., Gambardella, A., and Saxenian, A., 2001, "Old Economy Inputs for New Economy Outputs: Cluster Formation in the New Silicon Valleys", Industrial and Corporate Change 10 (4): 835-860.

Breznitz, D., 2005, "Software tooling: The Evolution of the Israeli Software Industry", in The Rise and Growth of the Software Industry in Some Emerging Economies, Arora, A. and Gambardella, A. (eds.) Oxford University Press, Oxford UK, forthcoming.

Carrington, W., and Detragiache, E., 1998, "How Big is the Brain Drain", IMF working paper no. 98, IMF, Washington DC.

DaCosta, 1998, “Technology Leapfrogging: Software Industry in India”, Presented at the 2nd International Conference on Technology Policy and Innovation, Calouste Gulbenkian Foundation, Lisbon, August 3-5.

Dornbush, R., Fisher, S., and Paul A. Samuelson (1977) "Comparative Advantage, Trade and Payments in a Ricardian Model with a Continuum of Goods", American Economic Review 67: 823-839.

Enos, J.L., 1962,_Petroleum Progress And Profits A History Of Process Innovation, MIT Press, Cambridge MA. 
Gambardella, A., and Ulph, D., 2003, “Technology, Entrepreneurship and Inequality”, LEM working paper, Sant'Anna School of Advanced Studies, Pisa, Italy.

Giarratana, M., Torrisi, S., and Alessandro Pagano, 2005, "The Role of MNCs in the Evolution of the Software Industry in India, Ireland, and Israel", in The Rise and Growth of the Software Industry in Some Emerging Economies, Arora, A. and Gambardella, A. (eds.) Oxford University Press, Oxford UK, forthcoming.

Gomory, R. E., and Baumol, W.J., 2000, Global Trade and Conflicting National Interests, MIT Press, Cambridge MA.

Heeks, R., 1996, India's Software Industry: State Policy, Liberalization And Industrial Development, Sage Publications.

Hicks, J., 1953, “An Inaugural Lecture”, Oxford Economic Papers 5: 117-135.

IT Workforce Update, 2003, "The Outlook in 2003 for Information Technology Workers in the USA", Commission on Professionals in Science and Technology, available from http://www.cpst.org/ITWF_Report.cfm (last viewed, 3rd May 3, 2004).

Kapur, D., and McHale, J., 2005, "Sojourns and Software: Internationally Mobile Human Capital and the Software Industry in India, Ireland and Israel" in The Rise and Growth of the Software Industry in Some Emerging Economies, Arora, A. and Gambardella, A. (eds.) Oxford University Press, Oxford UK, forthcoming.

Kline, S. and Rosenberg, N., 1986, “An Overview of Innovation”, in The Positive Sum Strategy, Landau, R. and Rosenberg, N. (eds.), National Academy Press, Washington DC.

Lamoreaux, N., and Sokoloff, K., 1996, "Long Term Change in the Organization of Inventive Activity", Proceedings of the National Academy of Science 93, 12686-12692

Lamoreaux, N., and Sokoloff, K., 1997, "Location and Technological Change in the American Glass Industry during the Late Nineteenth and Early Twentieth Centuries", NBER WP \#5938, Cambridge MA.

Mann, C., 2003, "Globalization of IT Services and White Collar Jobs: The Next Wave of Productivity Growth”, International Economics Policy Brief, Number PB03-11, December.

Mariani, M., 2001, "Next to Production or to Technological Clusters? The Economics and Management of R\&D Location", Journal of Management and Governance 6 (2), 131-152.

McKinsey Global Institute (MGI), 2003, Offshoring: Is It a Win-Win Game?, McKinsey \& Co. Inc., San Francisco CA.

OECD, 2001, Education at Glance, OECD, Paris.

OECD, 2002, Education at Glance, OECD, Paris.

O'Gorman, C., O’Malley, E. and Mooney, J., 1997, Clusters in Ireland. The Irish Indigenous Software Industry: An Application of Porter's Cluster Analysis, NESC, National Economic and Social Council, Research Series, Research Paper N. 3, November.

Rauch, J., 2001, "Business and Social Networks in International Trade" Journal of Economic Literature 39: 1177-1203.

Sands, A., 2005, "Eye of the Tiger: Evolution of the Irish Software Industry", in The Rise and Growth of the Software Industry in Some Emerging Economies, Arora, A. and Gambardella, A. (eds.) Oxford University Press, Oxford UK, forthcoming.

Sutthiphisal, D., 2004, “The Geography of Invention in High- and Low-Technology Industries: Evidence from the Second Industrial Revolution" Working paper, Department of Economics, UCLA. 
Saxenian, A., 2002, Local and Global Networks of Immigrant Professionals in Silicon Valley, Public Policy Institute of California, San Francisco.

Saxenian, A., 2003, "Government and Guanxi: The Chinese Software Industry in Transition", paper presented at the Conference Global Software from Emerging Markets: An Engine for Growth?, London Business School, May 12.

Tschang, T., and Xue, L., 2005, "The Chinese Software Industry: The Implications of a Changing Domestic Market for Software Enterprises", in The Rise and Growth of the Software Industry in Some Emerging Economies, Arora, A. and Gambardella, A. (eds.) Oxford University Press, Oxford UK, forthcoming. 
Table 1. The Software Industry in Brazil, China and the 3ls, and by comparison in the US, Japan and Germany - 2002 or latest available figures

\begin{tabular}{lccccc}
\hline Countries & $\begin{array}{c}\text { Sales } \\
\text { (\$ billion) }\end{array}$ & $\begin{array}{c}\text { Empl } \\
(000)\end{array}$ & $\begin{array}{c}\text { Sales/ } \\
\text { Empl } \\
(000)\end{array}$ & $\begin{array}{c}\text { Software } \\
\text { Sales/GDP (\%) }\end{array}$ & $\begin{array}{c}\text { Software } \\
\text { Development } \\
\text { Index }\end{array}$ \\
\hline Brazil * & 7.7 & $160 * *$ & $45.5 * *$ & 1.5 & 0.22 \\
China & 13.3 & $190 * *$ & $37.6 * *$ & 1.1 & 0.23 \\
India & 12.5 & 250 & 50.0 & 2.5 & 0.96 \\
Ireland (MNE) & 12.3 & 15.3 & 803.9 & 10.1 & 0.34 \\
Ireland (Domestic) & 1.6 & 12.6 & 127.0 & 1.3 & 0.04 \\
Israel * & 4.1 & 15 & 273.3 & 3.7 & 0.17 \\
& & & & & \\
US & 200 & 1024 & 195.3 & 2.0 & 0.05 \\
Japan ** & 85 & 534 & 159.2 & 2.0 & 0.08 \\
Germany * & 39.8 & 300 & 132.7 & 2.2 & 0.09 \\
\hline
\end{tabular}

Various sources. $*=2001 ; * *=2000$;

The Software Development Index is the ratio between Software Sales over GDP (in \%) and the GDP per capita of the country (in 000 US \$) (See also Botelho et al, 2005)

Table 2. Brazil, China and the 3Is: Software Industry Growth \& Export Shares

\begin{tabular}{lcc}
\hline Countries & $\begin{array}{c}\text { Average Growth } \\
\text { in the 1990s (\%) }\end{array}$ & $\begin{array}{c}\text { Exports as \% of sales (2002 or latest } \\
\text { available year) }\end{array}$ \\
\hline Brazil & 20 & $1-2$ \\
China & $30-35$ & 11 \\
India & 40 & 80 \\
Ireland & 20 & 85 \\
Israel & 20 & 70 \\
\hline
\end{tabular}

Various Sources. 
Table 3. Distributions of EU Structural Funds 1989-1993 and 1994-1999 (\%)

\begin{tabular}{lcccc}
\hline Country & \multicolumn{2}{l}{ Human Resources } & \multicolumn{2}{l}{ Infrastructure } \\
& $1989-$ & $1994-$ & $1989-$ & $1994-$ \\
& 1993 & 1999 & 1993 & 1999 \\
Greece & 25.6 & 24.6 & 40.9 & 45.9 \\
Spain & 24.2 & 28.4 & 54.0 & 40.4 \\
Ireland & 38.0 & 43.9 & 27.7 & 19.7 \\
Portugal & 26.1 & 29.4 & 29.2 & 29.7 \\
Italy & 21.6 & 21.4 & 38.7 & 29.8 \\
\hline Average & 29.6 & 29.8 & 35.2 & 29.5 \\
EU11 & & & &
\end{tabular}

Source: First Report on Economic \& Social Cohesion 1996 DG XVI EC Brussels, taken from Sands (2005) 
Table 4.

1) Selected Foreign Born Populations in the United States Aged 25 and Over

\begin{tabular}{|c|c|c|c|c|c|c|c|}
\hline & \multirow[b]{2}{*}{1990} & \multirow[b]{2}{*}{2000} & \multirow{2}{*}{$\begin{array}{l}\% \\
\text { Chng }\end{array}$} & \multirow{2}{*}{$\begin{array}{l}\% \text { of } 2000 \\
\text { population } \\
\text { entering post } \\
1990\end{array}$} & \multicolumn{3}{|c|}{ Educational Attainment (2000) } \\
\hline & & & & & $\begin{array}{l}\text { Primary } \\
\%\end{array}$ & $\begin{array}{l}\text { Second. } \\
\%\end{array}$ & $\begin{array}{l}\text { Tertiary } \\
\%\end{array}$ \\
\hline India & 304 & 837 & 175 & 55 & 5 & 15 & 80 \\
\hline Brazil & 54 & 154 & 186 & 49 & 9 & 36 & 55 \\
\hline China & 405 & 847 & 109 & 66 & 20 & 26 & 54 \\
\hline
\end{tabular}

2) Selected Foreign-Born Populations in the United States by Year of Entry

\begin{tabular}{lrrr}
\hline & Indian-Born & Irish-Born & Israeli-Born \\
Before-1960 & $1 \%$ & $32 \%$ & $4 \%$ \\
$1960-1969$ & $3 \%$ & $19 \%$ & $1 \%$ \\
$1970-1979$ & $14 \%$ & $8 \%$ & $28 \%$ \\
$1980-1989$ & $24 \%$ & $23 \%$ & $35 \%$ \\
$1990-1995$ & $23 \%$ & $13 \%$ & $18 \%$ \\
$1996-2001$ & $36 \%$ & $5 \%$ & $14 \%$
\end{tabular}

Source: Kapur and McHale (2005). (Original data from the March 2001 Current Population Survey of the U.S.) 
Figure 1

India, Ireland, Israel: SW Export Shares 1991-2002

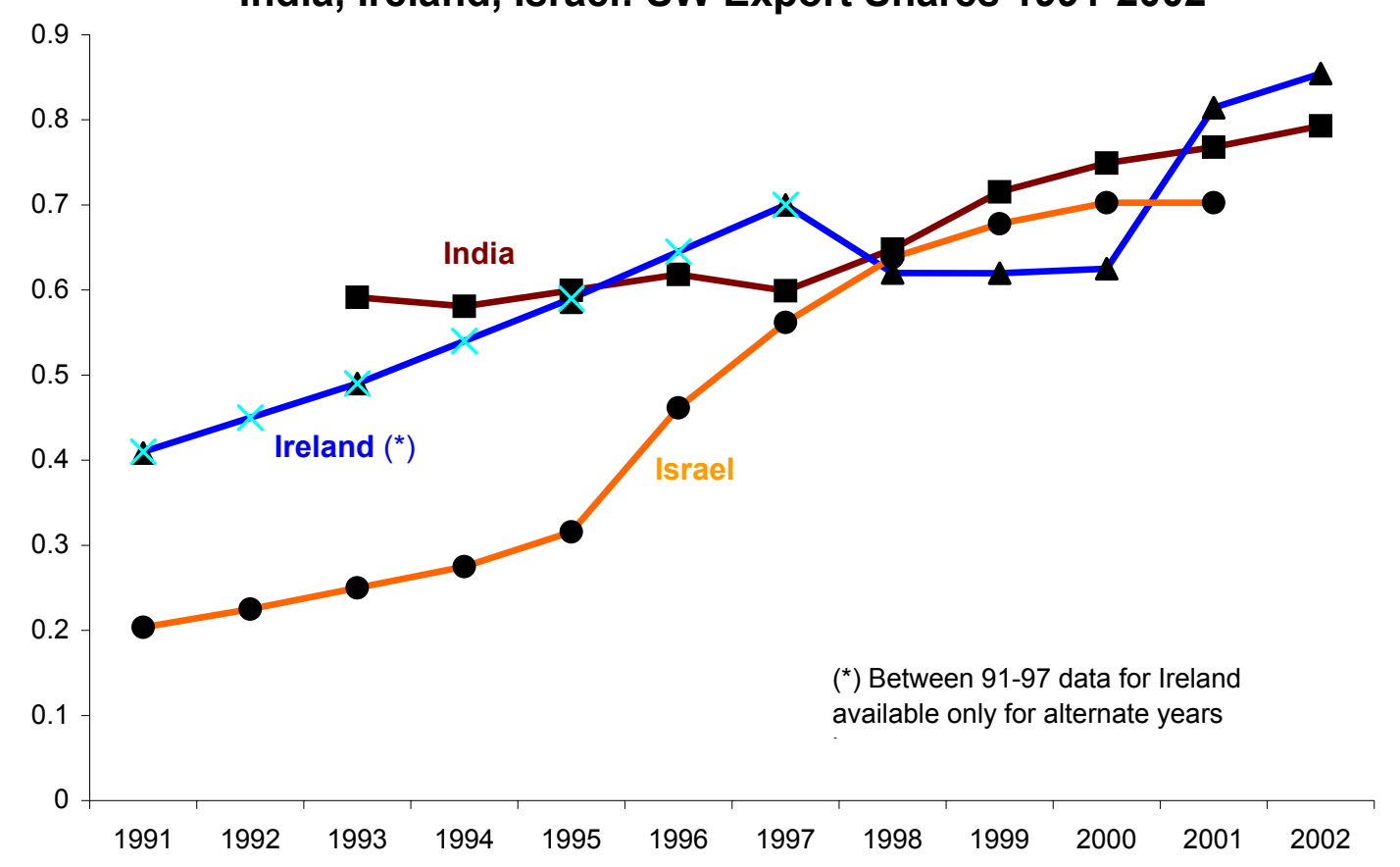

Source: Arora and Gambardella (2005) 
Figure 2

Share of Privately Financed Colleges in Indian IT Capacity, by

Region and Year

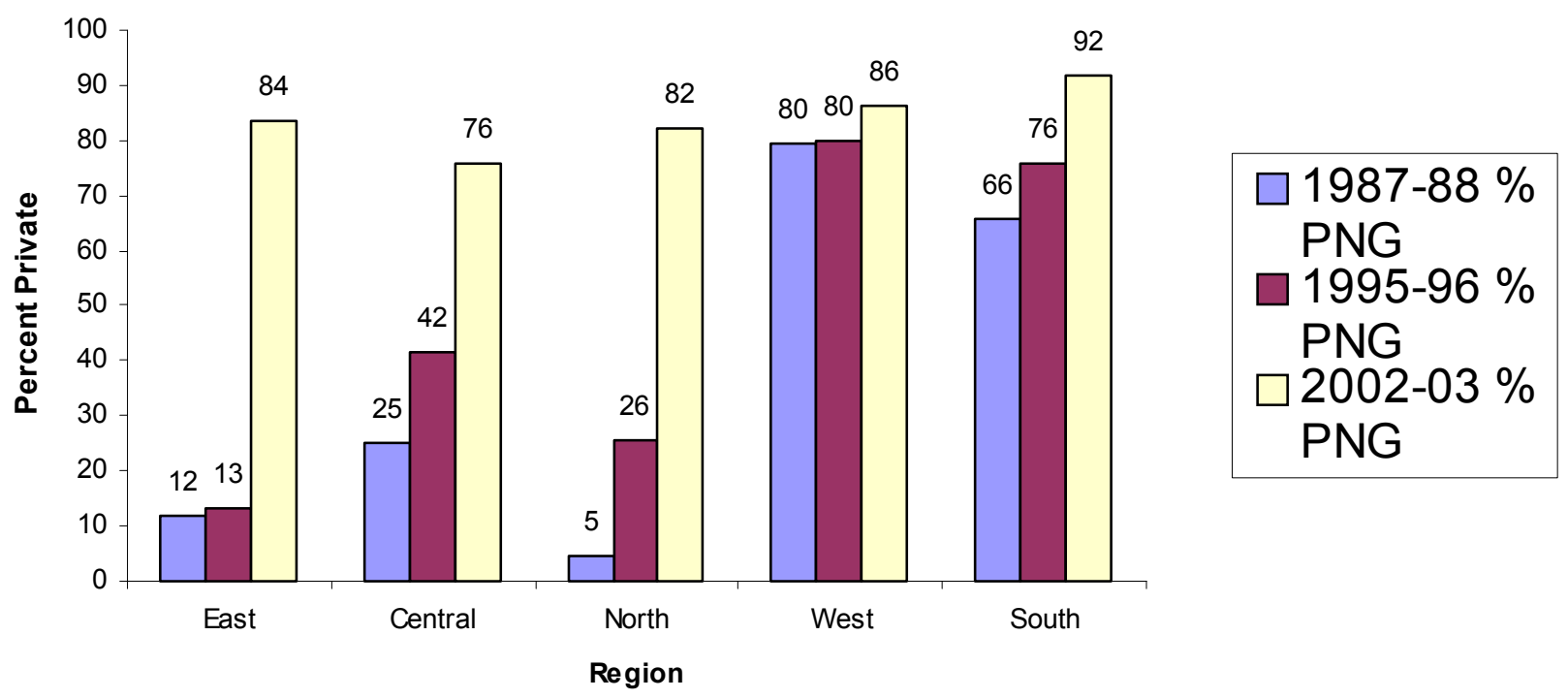

Notes: PNG refers to "Private Not Granted", which are privately financed colleges.

Source: Based on data from the All India Council on Technical Education (AICTE). More details are available on request. 